\title{
Digitaliserede læringsfællesskaber - netstuderende og deres studiestrategier
}

\author{
Anita Lyngsø, lektor, ph.d., VIA University College \\ Karen Borgnakke, professor, dr.pæd., Københavns Universitet, Sektion for Pædagogik
}

\begin{abstract}
Denne artikel baseres på etnografisk feltforskning og undersøgelser i en netbaseret sygeplejerskeuddannelse. Artiklen fokuserer på, hvordan netstuderende udvikler strategier til at håndtere den nye online læringskontekst. Empirisk baseres artiklen på data fra observationer og interviews fortaget hjemme hos de studerende. De studerende er fulgt i et toårigt forløb.

Feltforskningens kortlægning og analyser viser, hvordan Netuddannelsens e-pædagogiske design fremmer studerendes udvikling af strategier til aktiv og selvstændig håndtering af sygeplejestudiets digitale undervisningsforløb. Det e-pædagogiske design sikrer imidlertid ikke i sig selv den studiemæssige succes. Succesen synes i stedet at blive sikret gennem de netstuderendes selvforvaltende udvikling af studiegrupperne til digitaliserede læringsfællesskaber. De digitaliserede læringsfællesskaber fordrer selvforvaltning af teknologibrugen, samt at de studerende formår at komme de faglige udfordringer i møde i online læringskonteksten. På denne baggrund diskuteres, hvilken betydning indførelse af digitale undervisningsforløb i ellers campusbaserede uddannelser, kan have for studerendes læringsudbytte i henholdsvis højt og lavt præsterende studiegrupper.
\end{abstract}

\section{Engelsk abstract}

This article is based on ethnographic studies following an internet-based online nursing educational program. The article focuses on how online students develop strategies to handle a new online learning context. The empirical background consists of empirical data from observations and interviews conducted in students' homes. The students have been followed through a period of two years.

The ethnographic studies and subsequent analyzes show how the online education's e-pedagogical design contributes to the development of active and independent students. However, the epedagogical design does not in itself ensure academic success. Rather, the success seems to be ensured through the online students' self-managed development of the study groups into digitized learning communities. The digitized learning communities demand self-management of the learning environment and of the necessary technology acquisition, as well as the ability to be challenged and to challenge fellow students academically in the online learning context. Finally, the article discusses what the introduction of digital learning courses, in otherwise campus-based educations, means in terms of students' learning outcomes. 


\section{Introduktion}

De netstuderendes udvikling af digitaliserede læringsfællesskaber er en hovedpointe i de empiriske analyser, som feltforskningens studier af Netuddannelsens e-pædagogiske forløb udpeger (Lyngsø, 2019)i. Med reference til den samlede fremstilling fokuserer denne artikel særskilt på de netstuderende og deres strategiske håndtering af online undervisning. Hermed sættes fokus på de netstuderendes håndteringer af faglige og digitale forløb som studiearbejde i hjemlige omgivelser og som online/digitalt medieret gruppearbejde. Den strategiske håndtering betyder håndtering af online-forløbets skift mellem formelle og uformelle læringssituationer og håndtering af underviserløse perioder. I praksis henviser onlineforløbet til læringssituationer, hvor netstuderende sidder med studiearbejdet aften og weekend, hvor underviserne ikke nødvendigvis er tilgængelige. Provokeret af omstændighederne, er studiegrupperne 'nødt til' at blive deres egne mestre. I lyset af dette skal artiklens analytiske gennemgang af de netstuderendes udvikling af strategier og læringsfællesskaber ses.

\section{Baggrund}

I uddannelsesregi har spørgsmålet om online uddannelsers læringsmæssige kvalitet, sammenlignet med campusbaserede uddannelser, været et omdrejningspunkt (Lahti et al., 2014; Li, 2013; McCutcheon et al., 2015; Parlakkilic, 2015; Voutilainen, 2017). Tilsvarende har e-pædagogiske retninger været debatteret og eksempelvis knyttet til spørgsmålet om kollaborativ læring. For studerende synes det gennemgående spørgsmål at dreje sig om den fleksibilitet, som online uddannelsesformer giver. Uanset hvilke spørgsmål, der sættes højt på dagsordenen, er opnåelse af IT-færdigheder og 'det teknologiske' dog omdrejningspunkt i store dele af litteraturen (Allan et al., 2013; Button et al., 2014; Douglas, 2016; Griffiths, 2016; Hoffmann \& Dudjak, 2012; Posey \& Pintz, 2017; Sword, 2012).

Med spørgsmålet om IT-færdigheder som omdrejningspunktet, kan flere forskellige koblinger til spørgsmål om færdigheder dernæst iagttages. McIntyre m.fl. (2013) gengiver fx, hvordan studerende retrospektivt har oplevelsen af at have udviklet 'online færdigheder', som nedsatte konflikterne i studiegrupperne. I et litteraturreview har Patterson m.fl. (2012) fundet, at studerende bliver mere uafhængige, selvstyrende og tror på egne vurderinger. Denne type fund og koblinger mellem ITfærdigheder og sociale håndteringsevner har baggrund i uddannelsesdesigns med fokus på kollaborativ læring. Andre litteraturreview har inkluderet studier, hvis fund på afgørende punkter synes modsatrettede, fx om der finder dybdelæring sted eller ej (Webb et al., 2017).

Skiftende koblinger og modsatrettede fund er karakteristiske men også problematiske, ikke mindst fordi de vidner om forskningsområdets divergerende betegnelser som distance learning, online learning, online education, blended learning etc. Forsøg på at præcisere henholdvsis de synkrone og asynkron træk eller betegne det nye fx som 'flipped learning' eller som 'hybrid læring' gør ej heller betegnelserne klarere. Vores analyse af to danske rapporter giver imidlertid anvendelige pejlemærker. En rapport fra Evalueringsinstituttet (2014) evaluerer e-læringsbaserede professionsuddannelser, der med den danske tradition i reference kan betegnes som fjernstudier. Disse fjernstudier kendetegnes ved fastholdelse af didaktisk fokus på de få face-to-face undervisningsdage. En rapport fra Rambølls Institut (2016) omhandler nationale og internationale eksperters syn på den optimale online uddannelse, hvor det didaktiske fokus er på de online perioder. De to rapporter blander, som praksis og forskningsområdet $\mathrm{i}$ øvrigt, stadig begreberne og konstruerer deres egne. I denne sammenhæng er pointen dog, at en komparativ analyse af rapporterne gør det muligt at operere med en pædagogisk grundlæggende skelnen mellem: Fjernstudier med fokus på campusdagene eller online-uddannelse med fokus på de online perioder.

Online uddannelse med fokus på online-perioderne er et design, som ifølge eksperter hører til elæringens fremtid (Rambøll, 2016). Som en del af fremtidens uddannelse skal Netuddannelsen, iværksat 
af VIA University College i 2012, ses. Netuddannelsen var også i VIAs egen optik at opfatte som et epædagogisk frontløber-initiativ.

\section{Undersøgelsesfelten}

Som uddannelse var Projekt Netbaseret Sygeplejerskeuddannelse (Netuddannelsen) et radikalt projekt. Det var ikke blot et modul eller et semester, men derimod hele sygeplejerskeuddannelsen, der skulle foregå online. Det var tillige en uddannelse, hvor netstuderende veksler mellem aktiviteter online og offline i skolen, hjemmet og klinikken. Udviklingsarbejdet og hermed Netuddannelsen blev italesat som et alternativt projekt med e-pædagogiske ambitioner, der handlede om 'mere end blot at sætte strøm til'. Som forskere, der fulgte implementeringsprocessen gennem pioner-årgangen, stod det hurtigt klart, at Netuddannelsen både var et organisatorisk og et pædagogisk udviklingsarbejde.

Netuddannelsen blev afviklet indenfor den gældende bekendtgørelse (Uddannelses- og Forskningsministeriet, 2008), men ellers viser analyser af Netuddannelsens forberedende faser og projektbeskrivelse, hvordan Projekt Netuddannelsen søger at være på forkant. Dels gennem udvikling af et Salmon inspireret e-pædagogisk koncept om e-moderation (Salmon 2011, 2002), dels gennem forberedelse af de netstuderende til at indgå i en digital og højteknologisk sundhedssektor. Den teknologiske forberedelse af netstuderende var nytænkende i sin opstart, mens den i lyset af den senere 2016 bekendtgørelsen snarere er lig det, der nu forventes af alle sygeplejestuderende (Uddannelses- og Forskningsministeriet, 2016). Uagtet officielle forventninger, er der til stadighed bekymringer om, hvorvidt fokus på IT og teknologi vil føre til forskydninger mellem 'den kolde teknologi og de varme hænder' i sygeplejerskeuddannelsen (Kolbæk, 2013; Fredskild, 2007; Pols \& Moser, 2009).

Det udviklede Salmon-inspirerede e-pædagogiske koncept blev tilpasset Netuddannelsens full-scale format i samspil med ønsket om inddragelse af mange teknologier. Salmons centrering om emoderationen, bliver for Netuddannelsen forskudt til centrering om e-tivitets-procedurerne (Lyngsø, 2019). E-tiviteter er undervisernes detaljerede beskrivelse af, hvordan netstuderende forventes at arbejde med det faglige stof og indeholder elementer, som kræver interaktion med medstuderende.

I det etnografiske studie blev Projekt Netuddannelsen, som organisatorisk og e-pædagogisk udviklingsarbejde, fulgt i perioden fra 2014-2019 med fokus på, hvordan læreprocesser organiseres som netbaserede processer. Brugen af e-tiviteterne var det bærende didaktiske element både $\mathrm{i}$ undervisernes planlægning og som guidance af studerende. Fortløbende observationer viser, at denne guidance og hele e-tivitets-strukturen fungerer som særlig nyttig og vigtig for de netstuderende. Samtidig er det tydeligt, at såvel e-tiviteterne som selve studielivet kræver strategisk håndtering af de netstuderende (Lyngsø, 2019).

Netuddannelsen bibeholdt enkelte dage hvert semester med undervisning på campus, ligesom det kliniske rum for læring var uberørt. Med overgangen til hovedsagelig online undervisning i teoretiske perioder tilføres således yderligere et rum til læring, et online rum for læring (Lyngsø \& Kirketerp Nielsen, 2016). I det nye online rum for læring forsvinder den kendte undervisningskontekst og dermed også de, for studerende, velkendte studiestrategier. Herved skærpes det forskningsmetodiske blik for undersøgelser af, hvordan studerende studiestrategisk navigerer i Netuddannelsen i praktisk forstand.

\section{Metodiske og teoretiske inspirationer}

Feltarbejdet er inspireret af etnografiske metoder (Hammersley \& Atkinson, 2007; Walford, 2008; Borgnakke, 1996). Som understreget i metodelitteraturen nødvendiggør forskning i onlinesammenhænge en nytænkning af de etnografiske fremgangsmåder (Hammersley, 2006; Borgnakke, 2019; Hine, 2000). Hvor kvalitetstrækket i det traditionelle etnografiske feltarbejde er feltforskerens 
tilstedeværelse: 'at være der', så udvides dette i online-miljøet til 'at være her og der', det vil sige at være online såvel som offline. Observationer af den digitale uddannelseskultur bliver således uundgåeligt mere kompleks (Dyke, 2013; James \& Busher, 2013; Landri, 2013; Mackay, 2005; Parker Webster \& Marques da Silva, 2013). Den etnografiske forskning fokuserer på digitale forløb og på læringens kontekster, men er samtidig optaget af, hvordan netstuderende socialt gebærder sig digitalt i den praktiske kontekst. Så selvom forskningsområdets fokus er det nye online rum for læring, skal studerendes traditionelle sociale kontekster som fx hjemmet stadig medtænkes.

Feltforskningens observationer hjemme hos netstuderende kombinerede online og offline observationer (Lyngsø 2019). Placeret skråt bag ved den netstuderende, havde observatøren frit udsyn både til skærmaktiviteter og til 'offline' aktiviteter, som kæledyr i skødet, brug af bøger samt skift mellem dokumenter. Ved online møder i studiegruppen var observatøren samtidig koblet på online, og studiegruppens arbejde og indbyrdes relationer kunne observeres. Det, at indsamle etnografisk værdifulde materialer ved at observere skiftende online og offline, er metodisk både beskrevet som en samtidig handling (Lyngsø, 2015) og som to adskilte metodiske udfordringer (Lyngsø, 2019, s. 52-55). Omfanget af det etnografiske materiale er som følger:

Tabel 1: Oversigt over omfanget af det etnografiske materiale

\begin{tabular}{|l|l|}
\hline \multicolumn{2}{|l|}{ Studerende, hjemme gennem 2 år: 9 studerende i alderen 26-53 år } \\
\hline Observationer/feltnoter & 15 dage (6-8 timer pr. dag) \\
\hline Interview & 21 \\
\hline Samtaler, optaget & 4 \\
\hline Billeder & 8 \\
\hline Observation af webinar (online møde med underviser) & 4 \\
\hline Dokumenter & Diverse \\
\hline & \multicolumn{2}{|l|}{} \\
\hline Tilladelser givet af: & Uddannelsesledere \\
\hline & Studerende \\
\hline & Undervisere \\
\hline & Datatilsynet \\
\hline & KU: personoplysninger (GDPR) \\
\hline
\end{tabular}


Kombinationen af observationer online og offline samt hjemme hos netstuderende gav et unikt indblik i, hvordan studerende i en netbaseret uddannelse studerer.

Såvel etisk som metodisk skal det at observere og interviewe studerende i eget hjem reflekteres som en overskridelse til privatsfæren. Amy B. Jordans refleksioner (2006) over aktørtildelte roller indeholder i den forbindelse interessante pointer. Jordan pointerer, at selvom forskeren aktivt søger at positionere sig, så reflekteres roller ikke alene af forskeren, men tildeles og ændres tillige af aktørerne i felten. Blandt de aktørtildelte roller skelner Jordan mellem rollerne: Forskeren som studerende, som gæst og som negativ agent (Jordan, 2006). I observation af de netstuderende blev flere af rollerne erfaret, men rollen 'forskeren som studerende', fyldte mest. Dermed fyldte den ikke-vurderende observatør, der er interesseret i at lære fra feltet, mest. Det gav i øvrigt anledning til adgang til alle typer aktiviteter og mulighed for at følge og spørge ind til 'alt', hvad der foregik i den netstuderendes studiehverdag og læringssituationer.

\section{Analyseprocessen og de inddragne strategi- og læringsbegreber}

Den systematiske analyseproces har flere inspirationskilder indeholdende mere generelle etnografiske tilgange (Hammersley \& Atkinson, 2007; Hastrup, 2015; Atkinson, 2015), samt mere konkrete. Julie Jones' fokus på "significant pieces of data" (Jones \& Watt, 2010, s. 161) samt fremhævelse af den tematiske og problemorienterede analysestrategi (Borgnakke, 2018; Kvale \& Brinkmann, 2009) hjalp først til at håndtere de mange dokumenter og genrer, dernæst til at ordne det empiriske materiale efter overordnede temaer og problemstillinger. De temaer, som netstuderendes lærings- og studiestrategier tydeliggjorde, er sammenfattet som:

\footnotetext{
* Selvforvaltning af det formelle ind i det uformelle læringsmiljø

* Strategisk håndtering af det digitale studiemiljø

* Strategisk udfordring af sig selv og medstuderende.
}

Analysen af temaerne relateret til udvikling af 'digitaliserede læringsfællesskaber' og fastholdelse af de læringsmæssige konsekvenser, henter inspiration fra Jean Lave \& Etienne Wenger (1991, 2003). Desuden inddrages Karen Borgnakkes empirisk baserede begreber om universitetsstuderendes og gymnasieelevers læringsstrategier (Borgnakke, 1996, 2008) for at præcisere de netstuderendes strategier.

I samspillet mellem de empiriske og teoretiske pointeringer eksemplificeres dette $\mathrm{fx}$ som følger: netstuderende gik strategisk til værks, når de skulle håndtere Netuddannelsens udfordringer og krav til dem som studerende. Forståelsen af strategibegrebet ligger her på linje med Borgnakkes pointeringer:

\section{"I udspringet var det nemlig ikke et spørgsmål om de gode eller dårlige strategier. Pointen var, at det var elevernes egne strategier. Det interessante var, hvordan elever og studerende udvikler deres egne strategier og satte dem i værk" (Borgnakke, 2008, s. 56).}

Den analytiske interesse for strategibegrebet koncentreres således om de netstuderendes egne strategier, som de udvikles i studieforløbet og sættes i værk omkring læringssituationer. Her forbindes lærings- og studiebegreber med den sundhedsfaglige uddannelseskontekst, som de netstuderende befinder sig i, og som beslægtede kontekstnære etnografiske analyser fastholder (Røn Noer, 2016; Kirketerp Nielsen, 2018). Fokus for analysen bliver herved kontekstnære situationer og processer, hvor netstuderende udvikler strategier for at balancere studiet i relation til familie, arbejde og studiegruppen. Dette betyder, at de netstuderendes udvikling af strategier, med en Lave-Wenger inspireret formulering, relateres til studiets praksisfællesskaber (Lyngsø, 2019). 
Med inddragelse af Lave og Wengers koncepter om 'praksisfællesskaber' og 'legitim perifer deltagelse' (2003) skærpes samspillet mellem den teoretiske og empirisk-analytiske karakteristik af forholdet mellem netstuderendes læringsmiljø, læringssituationer og praksisfællesskaber. Et praksisfællesskab giver deltagerne "en fælles forståelse af, hvad de laver, og hvad det betyder i deres liv og for deres fællesskaber" (Lave \& Wenger, 2003, s. 83). Den legitime perifere deltagelse præciserer tillige en hierarkisk relation mellem 'mester og lærlinge' med mesteren som den vidende på området. Denne forståelse sætter observationerne af de netstuderendes læringssituationer i relief. Netstuderende studerer oftest uden tilstedeværelse af underviseren. Dermed er 'den vidende mester' ikketilstedeværende. Desuden beder netstuderende sjældent om vejledning. De gør for så vidt alene brug af det, som Lave og Wenger betegner 'ligestillede relationer'. Disse ligestillede relationer udspiller sig for netstuderende i deres studiegruppe. Studiegruppen kan derfor anskues som de studerendes praksisfællesskab, der tillige har deres egen 'læreplan'. Ifølge Lave og Wenger skal dette, praksisfællesskabets egen læreplan, anskues som en kontrast til den institutionelle undervisningsplan (Lave \& Wenger, 2003).

I Netuddannelsen er den institutionelle undervisningsplan e-pædagogisk dimensioneret og lig med undervisernes udarbejdede e-tiviteter. Læreplanen skabes derimod indenfor praksisfællesskabets praksis som "et felt af læringsressourcer i hverdagspraksis set fra de lærendes perspektiv" (Lave \& Wenger, 2003, s. 82). Det er således ikke blot deltagelse i praksis, som har betydning for netstuderendes læringsmiljø, men tillige studiegruppens læreplan og læringsressourcer, som făr betydning for læringsudbyttet.

Den enkelte studiegruppes læreplan, formet af gruppens særegne læringsressourcer og strategier, bekræftes af fortløbende feltobservationer. Undervejs i de netstuderendes arbejde med e-tiviteter iagttages deres strategiske håndtering af den formelle undervisningsplan i samspil med studiegruppens håndtering af deres egen plan. Her bliver forskellige former for læringsudbytte italesat af netstuderende, der, gennem studiegruppens arbejde, fortæller om et højt læringsudbytte, men også af netstuderende, der stadig 'kæmper for at få studiegruppen til at fungere'. Et velfungerende praksisfællesskab i studiegruppen synes, for netstuderende, at blive en forudsætning for at kunne håndtere det nye studiemiljø.

\section{Analyse og fortolkning - de digitaliserede læringsfællesskaber}

Analytisk bliver det tydeligt, at for netstuderende handler det om at udvikle strategier, der kan bruges til at håndtere og ikke mindst selvforvalte det digitale studieliv. Selvforvaltningen ses som studiestrategiske handlinger i forhold til at skabe tid og rum, når det formelle læringsrum forskydes ind i det uformelle læringsrum derhjemme. Selvforvaltningen fordrer desuden, at netstuderende formår at udvikle en udfordringsorienteret tilgang til medstuderende i studiegruppen.

I det følgende udfoldes disse studiestrategiske elementer således, at de netstuderendes håndteringer af den formelle undervisningsplan (e-tivitetsforløbet) belyses først. Dernæst belyses studerendes og studiegruppens selvforvaltede læreplaner. Gennem netstuderendes strategier iagttages, hvordan de håndterer det digitale forløb og dets uddannelsesfaglige og sociale dimensioner. Afslutningsvis sammenfattes dette som den vigtige ballast for udviklingen af det, vi har benævnt det digitaliserede læringsfællesskab. For yderligere uddybelse se Lyngsø’s ph.d.-afhandling (2019, kap. 8-11). 


\section{Studerendes forvaltning af den formelle undervisningsplan}

Analysens udgangspunkt er, at netstuderende værdsætter e-tiviteterne som strukturende element. De værdsætter særligt e-tiviteternes instruktive detaljer, hvor de får viden om, hvad der er forventet, og hvornår det er forventet. E-tiviteterne opleves som en rettesnor, der giver struktur og hjælp til at planlægge studiet.

For analysen af netstuderendes studiestrategier er det interessant, at de studerende fra første færd omtaler e-tiviteter som et planlægningsværktøj, hvor de, sammen med studiegruppen, tager arbejdet med e-tiviteterne i egen hånd. Planlægningsværktøjet og studiegruppen bliver, som en netstuderende udtrykker det, garant for "at vi kan arbejde os igennem emnet" (evaluering, studerende). I analysen af de netstuderendes strategier, er det således vigtigt, at hæfte sig ved netstuderendes erklærerede behov for en klar struktur for det faglige indhold og for interaktion med studiegruppen.

Gennemgående fremhæver netstuderende sig selv som såvel aktive som selvstændige, og 'aktivitet og selvstændighed' regnes for vigtige forudsætninger for at kunne gennemføre en netbaseret uddannelse. Desuden lærer man mere, når man selv er aktiv, som det understreges af netstuderende nedenfor:

\footnotetext{
"Jeg lærer meget, meget mere ved det her [Netuddannelsen], fordi jeg skal bruge mig selv meget mere [...] Nu skal jeg selv være aktiv" (interview, Jytte)

"Fordi vi sidder selv, og fordi vi ikke bare sidder og læser og kommer op til en forelæsning ... men der bliver stillet et krav om, at vi selv skal få fortolket den her litteratur over i den her opgave. Og det lærer man mere ved [...] vi skal anvende den teori, som vi har læst [...] vi får også sat vores egne ord på" (interview, Dicte)
}

Netstuderende italesætter selv deres tidligere erfaringer med face-to-face undervisning og sætter online undervisning i kontrast til face-to-face undervisningen. Det er tydeligt, at de netstuderende ser en læringsmæssig ressource samt højere læringsudbytte i selv at skulle sætte ord på og arbejde med stoffet i stedet for, som campusstuderende, at "læse pensum og komme op til en forelæsning, hvor du så hører pensum én gang til" (interview, Gitte).

Gennemgående viser analyserne således, at det e-pædagogiske design og den formelle undervisningsplan forvaltes af de netstuderende som strukturende for studielivet og som en aktiv etivitet-orienteret studiestrategi, der iværksættes for at mestre de undervisnings- og læringssituationer, som Netuddannelsens formelle studie- og undervisningsplan kræver. Denne forvaltning af det formelle e-pædagogiske forløb og dets uddannelsesfaglige dimensioner sættes imidlertid også i relief af studiegruppens uformelle læreplan, som det udfoldes nedenfor.

\section{Selvforvaltning af det formelle ind i det uformelle}

Med fokus på, hvordan netstuderende strategisk forvalter hjemmet som en læringskontekst, og hvordan de håndterer sammenstødet mellem de formelle og uformelle læringsmiljøer, flytter Netuddannelsens officielle rammer, mål og planer så at sige over i det hjemlige og uformelle læringsmiljø.

Ikke alt fra det formelle læringsrum flytter dog med over i det uformelle. Grundet online studiemiljøets fysiske fravær af både undervisningslokale og underviser, har netstuderende ikke adgang til de lærerhandlinger, der ifølge klasserumsforskningen karakteriserer dét at modtage undervisning (Lindblad \& Sahlström, 2003; Wulf, 2012). For de netstuderende er der ingen underviser, der markerer starten af undervisningen, understøtter de studerendes motivationen i løbet af dagen eller afslutter dagen. Den analytiske pointe er ikke, at de netstuderende oplever dette som et savn, men derimod at de i stedet selv skal varetage disse handlinger og funktioner. Netstuderende tager denne ansvarsoverdragelse på sig og overtager således handlinger, som i det formelle læringsrum ligger hos 
underviseren. De netstuderende fremstår herved som selvstændige og aktive studerende, om end det til stadighed er indenfor rammerne af undervisernes e-tiviteter (Lyngsø \& Kirketerp Nielsen, 2016).

Der er dog også elementer fra det formelle, som flytter over i det ellers uformelle læringsmiljø i hjemmet og hverdagslivets praksis. Studerende kender fra tidligere studieerfaringer til 'at være hjemme' med forberedelse og eksamenslæsning. Nu er situationen dog ny. $\mathrm{Nu}$ er det hele studieugens 40 timer, der skal struktureres med online gruppearbejde, webinarer og asynkront samarbejde. Observationer foretaget hjemme hos de netstuderende tydeliggør, hvordan netstuderende i situationen 'derhjemme ved spisebordet' håndterer sammenstødene. Fx da en netstuderende bliver ringet op og svarer, at hun ikke kan snakke, for hun 'er i skole'. Adspurgt fortæller hun efterfølgende, at folk ofte fortsætter med at snakke, hvis hun blot siger, at hun sidder hjemme og studerer. Derimod er der fuld forståelse for, at hun ikke kan snakke, når hun er 'i skole'. Ved at referere til kendte betegnelser fra det formelle rum, er der forståelse for, at samtalen ikke kan finde sted. Samtidig sætter det uformelle rum, nemlig hjemmet, sig også igennem. Den observerede netstuderende var faktisk midt i et online gruppearbejde og besvarede alligevel opkaldet. Det ville hun givetvis ikke have gjort, hvis hun faktisk havde været i skole. I den forstand gør den hjemlige kontekst sig stedse nærværende som et familierum, der også er et skolerum.

Den hjemlige kontekst med de hverdagslige rytmer, gøremål og relationer 'trænger sig på' og præger studielivet. Som netstuderende beretter, skal man ikke tage for mange hjemlige gøremål på sig. Man skal lære at prioritere, som det understreges i et interview:

\begin{abstract}
"De første par moduler, der tror jeg ikke, at jeg har arbejdet 40 timer, fordi det var et spørgsmål om at finde ind i den der rytme med at være herhjemme og så ikke have fri alligevel. Der var nogle gange, hvor jeg lige skulle lære at prioritere, men det er i hvert fald kommet. At hvis vi havde en læsedag, så faktisk at læse i 8 timer, og ikke komme til at vaske tøj og sådan noget. Det er der bare slet ikke tid til mere (griner), så det har jeg lært". (interview, Gitte)
\end{abstract}

Præciseringen af modstillingen mellem at være hjemme og så alligevel ikke have 'fri', er gennemgående i netstuderendes fortællinger. At lære 'ikke at vaske tøj eller bage boller', kræver studiestrategier, som prioriterer studiets arbejdsrytme og distancerer sig fra hjemmets rytme.

Som således fastholdt, arbejder netstuderende på, at hjemmet ikke trumfer studiet. Analysen viser samtidig, at når netstuderende skaber plads til læringsrummet i hjemmet, så sker indretningen oftest på hjemmets præmisser. Især hos netstuderende, der ikke havde mulighed for kontorfaciliteter. Disse studerende sad ved spisebordet på en spisestuestol og var flyttet ind på rummets, dvs. køkkenets og hjemmets præmisser. De forsøgte ikke at efterligne 'kontor', og adspurgt havde ingen af de netstuderende overvejet at anskaffe sig fx en kontorstol. Når familien kom hjem, og der var brug for funktionen 'hjem', skulle det være nemt at lægge studie-tingene væk. Som sådan er det formelle rum i form af computer og bøger kun på besøg i hjemmet. Har blot én i husstanden brug for funktionen 'hjem', trumfer det 'studerekammer'. For de etnografiske analyser er pointen ved de illustrative detaljer, at de henviser til situationer, hvor de netstuderende lærer af de givne hjemme-betingelser. Dernæst (selv)forvalter de netstuderende strategisk de skiftende skoleagtige og hjemlige læringskontekster.

Netstuderendes selvforvaltning er samtidig i studiegruppen afhængige af 'hinandens' selvforvaltninger og håndteringer af det digitale studiemiljø. Dermed er de også afhængige af hinandens til- og fravalg.

\title{
Strategisk håndtering af det digitale studiemiljø
}

Som noget selvfølgeligt fylder det digitale i de netstuderendes håndtering af deres studieliv. Det ses både som en strategisk håndtering af den nødvendige teknologi og som en mulighed for at selvforvalte tilstedeværelse og opmærksomhed bag skærmen. 


\title{
Til- og fravalg bag skærmen
}

Som beskrevet i forrige afsnit, tog netstuderende ansvaret på sig og indgik selvstændigt og aktivt i det digitale studiemiljø. Observationerne hjemme hos netstuderende gav tillige blik for, at netop den digitale omgang med hinanden over Skype-lignende værktøjer også gav muligheder for fravalg. Hjemme hos en netstuderende, observeredes følgende situation:

\begin{abstract}
"Else sidder og kigger ud ad vinduet med armene over kors. Underviseren giver i webinaret (online) ordet til Else og hendes studiegruppe, men ingen svarer. Else gør ingen tilløb til at tænde sin mikrofon. Stilhed. Else rører sig ikke. Efter lidt tid siger en anden studerende online: "Der er vist ikke nogen"'" (feltobservation, Else)
\end{abstract}

I situationen sad forskeren ved siden af en netstuderende (Else), som både var der - og ikke var der. I e-pædagogisk forstand er situationen interessant. Underviseren kan ikke kalde den studerende Else frem, får ingen svar. Mikrofonerne er slukket. Underviseren må opgive at få kontakt. I læringsmæssig forstand er situationen tankevækkende, idet det bliver tydeligt, at netstuderende tager et strategisk valg ud fra, hvad de oplever som havende læringsværdi for dem.

Dette bekræftes af en anden observeret situation på online-møderne. Den netstuderende har logget sig ind og står hermed som tilstedeværende til mødet. Forskeren kan iagttage, hvordan den netstuderende undervejs laver kaffe og går ud og holder pause, uden at andre har mulighed for at notere hendes fravær. Det interessante, viser det sig, er dog ikke pausen og fravalget, men derimod den studerendes begrundelse. Hun fortæller, at den gruppe, som fremlagde i det givne kaffepause-tidsrum, ikke blev opfattet som nogen, som de i hendes gruppe kunne lære noget af. Ved at høre fremlæggelsen kunne man højest lære noget forkert. Tilsvarende forventede hun, at undervisers spørgsmål til gruppen var på så lavt et niveau, at de heller ikke øgede læringsværdien (interview, Karin). Derfor fravalgte hun gruppen. Eller som hun begrundede det, så valgte hun læringen til. Med reference til beskrivelser af læringsressourcer (Lave og Wenger, 2003), fremstod den fravalgte gruppe ikke som læringsressource og var derfor heller ikke en del af den observerede studerendes og hendes studiegruppes læreplan.

Der var dog også fravalg, som ikke skete med en begrundelse i læringsværdien. Som en netstuderende fortæller:

\footnotetext{
"Når jeg ikke er den, der skriver ned, hvad gruppen beslutter sig for at sætte i opgaven, har jeg næsten en tendens til at spille et spil eller sådan noget. Det er ikke så klogt, jeg ved det. Jeg tror ikke, at nogen af de andre studerende gør sådan noget. De er altid meget aktive". (interview, Else)
}

Den netstuderende foretager også her ting væk fra det online fællesskab. Ikke i en sådan grad, at hun ikke deltager i gruppearbejdet. Hendes opmærksomhed er dog delt, hvilket hun selv betegner, som 'ikke så klogt'. Pointen er, at der foregik og kunne foregå mange ting bag de enkeltes skærme uden andres vidende. Det strategiske til- og fravalg må derfor betragtes i samspil med online undervisningssituationen, netstuderendes vurderinger af, hvad der har læringsværdi, samt de muligheder den netbaserede kontekst og dens iboende IT-muligheder skaber.

\section{Teknologiske/digitale færdigheder}

Netuddannelsen havde som intention at uddanne studerende til at kunne indgå i 'det digitale og højteknologiske sundhedsvæsen'. Underviserne medtænkte flere forskellige værktøjer som fx blogs, wiki, diskussionsfora og optagelse af video som en del af netstuderendes arbejde med e-tiviteterne. Ses IT-inddragelsen fra undervisernes perspektiv drejer det sig om en fagdidaktisk og potentielt også professionsdidaktisk begrundet kompetenceudvikling. De netstuderende stiller imidlertid spørgsmål til dette, for som en studerende formulerer det i en diskussion om blog og wiki: 
"Det kunne være super fedt, hvis vi fik en forklaring på, hvordan bruger man - og hvad bruger man bloggen til ude i praksis? Hvordan skal vi bruge den i praksis, og hvordan skal vi bruge Wiki'en?" (evaluering, studerende, Modul 3)

Intentionen om, at teknologiinddragelse havde relation til professionen, blev opretholdt. Analyseres listen over Netuddannelsens anbefalede inddragelse af teknologier, er fokus dog klart på uddannelsesteknologier. Det vil sige fokus på teknologier, som bruges til at lære om det faglige indhold og ikke teknologier, som nødvendigvis bruges i den professionelle praksis.

De observerede netstuderende synes at have en pragmatisk håndtering af undervisernes krav om anvendelse af de forskellige teknologier. Selvom kravet fx var, at tekstproduktionen skulle foregå i en blog eller wiki, producerede studiegrupperne den oftest i Word, hvorefter den blev flyttet over i en wiki - og så blev det en wiki. I observationer hjemme hos netstuderende hørtes udtalelser som: "Det er nederen, at det skal sættes ind i en wiki, da det tit forandrer opsætningen i dokumentet" (feltobservation, Dicte). En anden gruppe oplever forvirring og irritation. De har lagt deres opgave ind i en wiki, men kan nu ikke finde den, som det fremgår af feltnotatet:

\footnotetext{
"Vi så jo alle tre, at Freja lagde den ind". Freja begynder at lede: "Hvor har jeg så lagt den henne? " og siger til Cecilie, om hun lige skriver til underviseren, at de har set, at den er blevet lagt ind, men at de nu vil prøve at finde den igen. Freja leder rundt på den bærbare i mapperne med dokumenterne. Cecilie har nu fundet deres litteraturliste, som de lagde ind samtidig i wiki'en, og den er der. De snakker om, hvor træls det kan være at arbejde i Wiki, og Freja fortæller om en tidligere oplevelse, hvor opgaven heller ikke blev gemt". (feltobservation, Freja)
}

De netstuderende er frustrerede over at skulle arbejde i wiki. Det ironiske er, at de netop ikke arbejdede i wiki men i Word. De har derfor Word-udgaven og kan blot indsætte den i wiki'en igen. Den udtalte forvirring refererede således også til anvendelse af teknologier, som netstuderende ikke var teknologisk kompetente til.

Andre teknologier og IT-redskaber valgte netstuderende derimod at blive kompetente brugere af. Det var nødvendigt med individuelle kompetencer, så LMS, online møde-værktøjer og Office-pakken kunne anvendes. Set fra netstuderendes perspektiv gav det mening at målrette inddragelse af teknologi efter hvad, der er nødvendigt for at interagere og kommunikere i studiegruppens læringsfællesskab.

Pointen er, at for netstuderende er det at lære om - og med teknologi ikke et mål i sig selv. Det er skolens mål. De studerende har søgt Netuddannelsen for at blive sygeplejersker, og som en studerende pointerer, bliver hun "jo sygeplejerske og ikke net-sygeplejerske” (interview, Karin). Strategisk prioriteres inddragelse af IT og teknologi således 'kun' i det omfang, som er nødvendigt for at komme gennem uddannelsen. At blive gode studerende trumfer, i første omgang, at blive gode IT-kompetente sygeplejersker.

\section{Strategisk udfordring af sig selv og medstuderende}

Netstuderende agerer, som tidligere beskrevet, som aktive og selvstændige studerende, der bliver ITkompetente i en grad, der gør det muligt at indgå i online gruppearbejde. Alligevel var det ikke alle studiegrupper, der lærte det forventede. Modulevalueringer vidner om undervisernes karakteristik af 'højt og lavt præsterende' studiegrupper. Ifølge underviserne var der 'stærke' og 'dygtige' grupper, ligesom der var grupper, som 'lige hang fast med neglene'. Med feltforskningens interesse for forløbet og netstuderendes studie- og læringsstrategier, snarere end deres høje/lave præstationer, kommer observerede forskelle i studiegruppernes arbejds- og læreprocesser i fokus. 
Observationer hjemme hos to forskellige netstuderende synliggjorde forskellene i de to studiegruppers håndtering af e-tivitetens instruks. De netstuderende blev bedt om at udvælge 1-2 af de sygeplejefænomener, som de allerede havde arbejdet med. De valgte fænomener skulle efterfølgende analyseres op imod en case og fremlægges for underviserne. Strategien hos den ene gruppe var at søge de nye udfordringer, og de valgte hurtigt at udvælge to fænomener. I forkortet form var deres drøftelser således:

\begin{abstract}
"Ane: "Hvilke problemer er vigtigst for Hanne [patienten i casen] at fa gjort noget ved". Heidi: "Her er urininkontinens ikke noget stort problem". De kommer frem til, at kvalme og opkast samt obstipation (forstoppelse) er de største problemer. Gitte kommer også med [forslaget], at de kunne fokusere på obstipation og lidelse. Dicte: "Fordelen ved urininkontinens er, at vi så skal omkring nyrerne". Gitte argumenterer også for kost og sygepleje, idet de så vil få gennemgået hele fordøjelsessystemet [...] De afslutter med at aftale "at vi til i morgen finder ud af, hvad vi har lyst at blive udfordret med at fremlægge $\mathrm{e}^{\prime \prime \prime}$ (feltobservation, Ane)
\end{abstract}

I denne studiegruppe forsøger de netstuderende strategisk af få mest mulig læring ud af den beskrevne opgave. De vil udfordre sig selv gennem arbejde med stofområder, som de endnu ikke er sikre indenfor og har samtidig øjnet muligheden for at få undervisernes feedback på disse områder og herved højne niveauet yderligere.

Den anden studiegruppe har en mere pragmatisk strategi. De udvælger kun ét fænomen, og det bliver det fænomen, som de føler, at de har mest styr på. Dels giver det dem mindre arbejde og dels ser de muligheden for at imponere underviserne. En af de netstuderende foreslår, at de deler fremlæggelsen ud mellem dem med det samme: "Kan vi ikke dele den ud nu, så vi kan læse på det" (feltobservation, Bettina). Strategien synes at være, at de på denne måde kan nøjes med at fokusere på deres egen del af fremlæggelsen. Et af gruppemedlemmerne er dog lidt nervøs for denne strategi og spørger de andre, om ikke det vil kunne have konsekvenser til eksamen, hvis de ikke er inde i hinandens dele af fremlæggelsen. De øvrige studerende i gruppen beroliger med, at også dette kan håndteres strategisk:

\title{
"Jytte: "Det kan jo være, at de spørger om det til eksamen". Cecilie: "De spørger ikke om det, hvis du ikke leder dem ind på det"'" (feltobservation, Bettina)
}

Strategisk er denne studiegruppe mere orienteret mod eksamenssituationen og tidsfaktoren end mod det læringsmæssige. Observationer af denne og tilsvarende 'lavt' præsterende grupper viser, at gruppens medlemmer er aktive og bruger tid på drøftelser. Drøftelserne bliver dog aldrig dybdegående, ligesom de ikke udfordrer hinandens argumenter og forståelser. Deres tilgang bærer præg af 'det du sagde der, lød godt. Skynd dig at skrive det ned'. Og en sådan strategi har konsekvenser. Ovenstående gruppe klarede sig ikke godt til eksamen - hverken i forhold til det faglig indhold eller i forhold til at styre eksaminators spørgsmål.

Grupper med en udfordringsorienteret strategi står i kontrast hertil. Det synkrone samarbejde præges i disse grupper af spørgsmål a la 'hvad mener du, når du siger...', ligesom de i deres asynkrone samarbejde sikrer en fælles forståelse ved enten at 'skrive oveni hinanden' i deres dokumenter eller ved at mødes, drøfte og tilrette individuelle bidrag, så de udgør et hele, inden de afleveres. Kun ved det, som højt præsterende grupper kalder 'dårlige' e-tiviteter, ses der sammenfald i den strategiske håndtering med de pragmatisk orienterede grupper. Dårlige e-tiviteter er kendetegnet ved, at svarene kan findes direkte i bøgerne, og de netstuderende ser derfor ingen grund til at drøfte dem efterfølgende.

Studiegrupper med en udfordringsorienteret strategi virker attraktive på nogle studerende fra de ellers pragmatisk orienterede grupper. I et interview fortæller Karin, at hun gerne vil være med i "Anes gruppe" (en gruppe med en udfordringsorienteret strategi). Karin kan se, at gruppen arbejder anderledes, men hun kan ikke selv få denne strategi til at virke. Hun har brug for gruppens praksisfælleskab, søger det og optages med positive konsekvenser. Som Karin beskriver det: 


\begin{abstract}
"Jeg synes også, at det her studie gør, at man kommer meget dybere i tingene, fordi man diskuterer rigtig meget, altså der er mange faglige diskussioner. Jeg ved faktisk ikke, om man kan sige, at det er for meget. Nogle gange synes jeg, at det fylder enormt meget og det tager lang tid, men jeg tror altså, at i den sidste ende [...] får man en masse ud af det. Det her med: 'hvorfor det'; hele tiden at stille spørgsmål." (interview, Karin)
\end{abstract}

Som Karin her beskriver det, så muliggør den udfordringsorienterede strategi at komme i dybden ved, at der hele tiden stilles spørgsmål til stoffet, til sig selv og sine medstuderende - og at det har den faglige konsekvens, at man som netstuderende 'får en masse ud af' at indgå i et sådant læringsfællesskab.

\title{
Studiegrupperne som digitaliserede læringsfællesskaber - en opsamling
}

Det er ikke særegent for netstuderende, at deres studiegrupper har forskellige arbejdsprocesser og læringsstrategier. Dette blev også fremhævet i etnografiske studier i campusbaserede kontekster (Christensen, 2013; Borgnakke, 1996). For netstuderende er det specielle, at inden de overhovedet kan indgå $\mathrm{i}$ en studiegruppe, er de, grundet den online kontekst, nødt til strategisk at have håndteret det formelle læringsmiljøs indtog i den hjemlige kontekst. De skal have skabt tid og rum til at studere. Tillige skal netstuderende have håndteret den nødvendige teknologitilegnelse, der muliggør interaktion med såvel studiegruppe som undervisere og beskrevne e-tiviteter/studieaktiviteter.

Studiegruppernes udvikling af en udfordringsorienteret strategi kan hævdes at være det foretrukne i enhver form for gruppearbejde, det være sig campus- eller onlinebaseret. I den online kontekst er overvejelser om det foretrukne imidlertid mere komplicerede. I det undersøgte Netuddannelses-forløb var det til stadighed en udfordring at få netstuderende til at søge vejledning. Underviserne var ganske vist tilstede med deres 'stemme' i e-tivitetet-forløbets instruktive beskrivelser af, hvad og hvordan de netstuderende skulle arbejde med det faglige indhold. Men i selve udførelsen i studiegruppen var underviserne fraværende. For karakteristikken inspireret af Lave og Wenger (2003) betyder det, at netstuderende og studiegrupperne i deres respektive praksisfællesskaber gennemførte forløb 'uden en mester'. Den empiriske analyses pointe er dernæst, at nogle af grupperne strategisk formåede at håndtere dette.

Studiegrupperne med den udfordringsorienterede strategi formåede nemlig at blive deres egne læremestre. De udviklede de ligestillede relationer, der foruden at praktisere og lære sammen, også inkluderede at udfordre hinanden og at lade sig udfordre. De udviklede således i deres studiegrupper digitaliserede læringsfællesskaber. At indgå i et digitaliseret læringsfællesskab viste sig tillige som værende den faktor, der bedst sikrede, at den netstuderende gennemførte uddannelsen (Lyngsø, 2019). Med dette som en 'ny' platform for diskussion af Netuddannelsens e-pædagogiske og online læringspraktiske potentialer, fastholdes aktuelle dilemmaer og perspektiver.

\section{Aktuelle dilemmaer og perspektiver}

De netstuderendes forløb og håndteringer perspektiverer såvel den formelle undervisningsplan (etivitetsforløbet) som studiegruppens selvforvaltede egne læreplaner. Ved at netstuderende håndterer det e-pædagogiske digitale forløb og dets uddannelsesfaglige dimensioner, sættes de underviserløse perioder i perspektiv af udviklingen af det digitaliserede læringsfællesskab. Dilemmaet er, at det ikke lykkes for alle studiegrupper at udvikle et digitaliseret læringsfællesskab, og netstuderende risikerer at gennemløbe de underviserløse perioder uden mestre og uden at lære det forventede.

Selve spørgsmålet om at lære/ikke at lære det forventede har, siden opstart af fjernstudier og online uddannelser, været i fokus. Men svarene har været divergerende og ind imellem modstridende. 
Vores svar peger på modsætninger og på forskelle mellem henholdsvis højt/lavt præsterende studiegrupper, deres arbejdsprocesser og det vurderede læringsudbytte. Forskellene er interessante, fordi de gennem grupperne, der peger på en udfordringsorienteret strategi, viser muligheden for at opnå et højt - også højere end forventet - læringsudbytte online. Således fastholder netstuderende i de højt præsterende grupper, at de lærer mere ved den online tilgang, end de tidligere har gjort i campusbaserede uddannelser. Højt præsterende grupper synes at håndtere såvel formelle epædagogiske forløb med underviserløse perioder som selvforvaltede forløb efter egne læreplaner. Omvendt viser grupperne, der anvender den pragmatiske strategi, risikoen for at stagnere på et lavt niveau og opnå et lavere end forventet læringsudbytte online. Lavt præsenterende grupper ophober vanskeligheder i de underviserløse perioder og undervurderer udfordringerne i arbejdet med egne læreplaner i de digitale forløb.

Dilemmaerne, i relation til de netstuderendes forskellige strategier og læringsudbytte, understreger de endnu ikke indfriede aspekter i det e-pædagogiske deasign. Efter intentionen understøttes netstuderendes læreproces af undervisernes detaljerede beskrivelser af form og indhold i e-tiviteterne. I selve udførelsen er underviserne imidlertid fraværende. Således bliver dannelse til at 'agere som online studerende' studiegruppens, og de netstuderendes eget ansvar. I forhold hertil peger vores analyser på, at de svagt præsterende netstuderende skal have støtte til at modtage denne overdragelse af ansvaret, og dermed skal have yderligere støtte til udvikling af studiestrategier og læringsfællesskaber.

Med en skelnen mellem højt og lavt præsterende grupper peges på en vigtig problemstilling, som også i beslægtede studier af online forløb sættes i forbindelse med studerendes (eller elevernes) egne håndteringer i læringsforløbet. Fx giver Monica I. K. Olesen (2020) en karakteristik af studerende på en efter- og videreudddannelse, som 'de blendede learnere' og identificerer fire forskellige profiler: "De selvstændige", "De synlige", ”De undersøgende" og "De opgivende". I artiklen "Gymnasieelevers dømmekraft - et undervisningskontekstuelt it-anvendelsesperspektiv" (Mathiasen et al., 2019) koncentrerer forfatterne karakteristikken om elevernes divergerende evner til at udvise dømmekraft i inddragelse af de digitale redskaber i skolesituationen. Her karakteriseres høj/lav grad af dømmekraft som digital dannelse og evne til at vurdere, hvad der har skolerelevans og hvad ikke. I vores sammenhæng, er spørgsmålet om dømmekraft relevant for diskussionen af de digitale læringsfællesskaber, hvor de studerende selvstyret kombinerer sociale medier, teknologier og digitale redskaber - 'hvad som helst', der tjener formålet. Netstuderende viser i praksis 'dømmekraft'.

I relation til vores analyser er en nuanceret karakteristik af elever og studerende som 'de lærende' et vigtigt omdrejningspunkt. Forskellige studier og typologier som fx ovennævnte er derfor både med til at nuancere og skærpe blikket for den egentlige udfordring, nemlig at e-pædagogik skal udvikles til at rumme de studerende som lærende, der kan have forskellige grader af vanskeligheder, men også flere forskellige strategier til at håndtere online studieforløbets undervisnings- og læringsbetingelser. Pointeringen af vigtigheden af udviklingen af digitaliserede læringsfællesskaber, samt eksemplificering af aktuelle udfordringer er her af betydning. Men samtidig understreges, at de e-pædagogiske udfordringer og de studerendes læringsudbytte skal ses i relation til det samlede uddannelsesforløb mere end i relation til enkeltstående aktiviteter. Snarere end punktvis indførelse af online studieaktiviteter (som fx e-tiviteter) i professionsorienterede uddannelser, peger vores fund på, at netop refleksioner over hele uddannelsesforløb er påkrævet.

Covid-19 nødundervisningen i foråret 2020 tydeliggør nødvendigheden med appeller, der både vedrører den punktvise indførelse og hele uddannelsesforløb. Appellen: Go online - transformer 'al' campusundervisning til en digital version må i praksis betragtes som urealistisk og risikerer at være stjerneeksempel på, at der blot sættes strøm til. I Covid-19-akutte situationer er der ikke tid til andet. Pointen er imidlertid, at selv om der blev givet tid til andet og mere end blot at sætte strøm til, som fx tid til e-pædagogiske refleksioner og eksperimenter, er budskabet 'go online' svært realiserbart. Der eksisterer ikke en 'one model fits all'. Og som Netuddannelsen og de etnografiske studier af forløbet har vist, så kræver det at transformere campusbaserede studier, fag, undervisere og studerende til online- 
undervisning både et omfattende fagnært e-pædagogisk udviklingsarbejde - og et blik for at understøtte studerendes udvikling af digitaliserede læringsfællesskaber.

\section{Konklusion og optakt til konkrete løsningsforslag}

De etnografiske analyser viser, at Netuddannelsens e-pædagogiske design fremmer aktivitet og selvstændighed blandt de netstuderende. Men især netstuderendes udvikling af studiegrupperne til digitaliserede læringsfællesskaber styrker selvforvaltningen af læringsmiljøet. De digitaliserede læringsfællesskaber fordrer selvforvaltning af den nødvendige teknologitilegnelse og udfordrer de netstuderende som 'hinandens medstuderende' i online læringskonteksten. I lyset heraf skal Netuddannelsens e-pædagogiske og læringspraktiske potentialer ses. Samtidig fastholdes aktuelle dilemmaer og perspektiverer.

At indgå i et digitaliseret læringsfællesskab er den faktor, der bedst sikrer, at den netstuderende gennemfører uddannelsen. Dilemmaet er, at ikke alle studiegrupper lykkes med atudvikle et digitaliseret læringsfællesskab. Netstuderende risikerer i så henseende at gennemløbe online-uddannelsen uden at lære det forventede. De højt præsterende grupper håndterer såvel de formelle e-pædagogiske forløb med underviserløse perioder, som de selvforvaltende forløb efter egne læreplaner. De lavt præsterende grupper ophober vanskeligheder i de underviserløse perioder og undervurderer udfordringerne $\mathrm{i}$ arbejdet med egne læreplaner i de digitale forløb.

Vigtigheden af udviklingen af digitaliserede læringsfællesskaber handler fremover om at støtte de netstuderende i denne dannelsesproces, såvel organisatorisk som pædagogisk. I stedet for læringsfællesskaber som kun enkelte studentergrupper formår at etablere, skal muligheder for, at undervisere og studievejledere aktivt og eksplicit kan understøtte alle studerende i processen etableres. Desuden skal støtten rettes såvel mod de studerendes selvforvaltning af hjemmet som studiested og den nødvendige teknologi, som mod tilegnelsen af en udfordringsorienteret strategi.

Undervisernes modul-evalueringer viser, at underviserne, på baggrund af opgaveafleveringer, har en klar fornemmelse for hvilke grupper, der kan betegnes som svagt præsterende. Muligheden er således også for en målrettet indsats for de svagt præsterende grupper. I Netuddannelsen har det ført til en praksis, hvor undervisernes vurderinger indsamles midtvejs og efterfølgende drøftes med de udpegede studiegrupper. En drøftelse, som ikke er vurderende, men snarere undersøgende i forhold til hvilke elementer, der skal understøttes i dannelsesprocessen hen imod digitaliserede læringsfællesskaber.

\section{Referencer}

Allan, H. T., O’Driscoll, M., Simpson, V., \& Shawe, J. (2013). Teachers' views of using e-learning for nontraditional students in higher education across three disciplines [nursing, chemistry and management] at a time of massification and increased diversity in higher education. Nurse Education Today, 33(9), 1068-1073.

Atkinson, P. (2015). For ethnography. SAGE.

Borgnakke, K. (1996). Procesanalytisk teori og metode. Thesis, Danmarks Universitetsforlag.

Borgnakke, K. (2008). Evalueringsstrategier-I den pædagogiske kontekst. I K. Borgnakke (Red.), Evalueringens spændingsfelter (s. 9-66). Klim.

Borgnakke, K. (2018). Cardinal Writing: Following the observed process. I B. Jeffrey \& L. Russell (Red.), Ethnographic writing (s. 45-65). E \& E Publishing.

Borgnakke, K. (2019). Ethnographic Methods for Researching Online Learning and E-Pedagogy. Oxford University Press. https://doi.org/10.1093/acrefore/9780190264093.013.542

Button, D., Harrington, A., \& Belan, I. (2014). E-learning \& information communication technology (ICT) in nursing education: A review of the literature. Nurse Education Today, 34(10), 1311-1323.

https://doi.org/10.1016/j.nedt.2013.05.002 
Christensen, G. (2013). Projekt grupper: En undersøgelse af subjektiveringsmekanismer i gruppe-og projektarbejde på universitetsniveau. Aarhus Universitet, Institut for Uddannelse og Pædagogik (DPU).

Danmarks Evalueringsinstitut. (2014). E-læring på læreruddannelsen og sygeplejerskeuddannelsen. Danmarks Evalueringsinstitut.

Douglas, T. ; S., Susan ;. Iglesias, Miguel ;. Dowlman, Michele ;. Eri, Raj. (2016). The Feedback Process: Perspectives of First and Second Year Undergraduate Students in the Disciplines of Education, Health Science and Nursing. Journal of University Teaching and Learning Practice, 13(1).

Dyke, S. (2013). Utilising a blended ethnographic approach to explore the online and offline lives of pro-ana community members. Ethnography and Education, 8(2), 146-161. https://doi.org/10.1080/17457823.2013.792505

Fredskild, T. U. (2007). Studieformer i sygeplejerskeuddannelsen. En analyse af sygeplejerskeuddannelsen udbudt i tre forskellige regi: under den traditionelle studieform, via fjernstudie og som merituddannelse. Fokus er lagt på analyse affjernstudieformen set i relation til de øvrige studieformer. Ph.d. afhandling.

Griffiths, B. (2016). A Faculty's Approach to Distance Learning Standardization. Teaching \& Learning in Nursing, $11(4), 157-162$.

Hammersley, M. (2006). Ethnography: Problems and prospects. Ethnography and Education, 1(1), 3-14. https://doi.org/10.1080/17457820500512697

Hammersley, M., \& Atkinson, P. (2007). Ethnography: Principles in practice (3rd ed). Routledge.

Hastrup, K. (2015). Feltarbejde. I S. Brinkmann \& L. Tanggaard (Red.), Kvalitative metoder. En grundbog (2. udg., s. 55-80). Hans Reitzels Forlag.

Hine, C. (2000). Virtual ethnography. SAGE.

Hoffmann, R. L., \& Dudjak, L. A. (2012). From Onsite to Online: Lessons Learned From Faculty Pioneers. Journal of Professional Nursing, 28(4), 255-258. https://doi.org/10.1016/j.profnurs.2011.11.015

James, N., \& Busher, H. (2013). Researching hybrid learning communities in the digital age through educational ethnography. Ethnography and Education, 8(2), 194-209. https://doi.org/10.1080/17457823.2013.792509

Jones, J. S., \& Watt, S. (Red.). (2010). Ethnography in social science practice. Routledge.

Jordan, A. B. (2006). Make yourself at home: The social construction of research roles in family studies. Qualitative Research, 6(2), 169-185. https://doi.org/10.1177/1468794106062708

Kirketerp Nielsen, C. (2018). Dyrlæge på spil... Uddannelsesetnografiske studier i professionsorinteret spilbaseret læring på den danske dyrlægeuddannelse. Københavns Universitet.

Kolbæk, R. (2013). Holdninger til brugen af it i teoretisk uddannelse og klinisk sygepleje hos nystartede sygeplejestuderende. Ph.d. Afhandling. Det Humanistiske Fakultet. Københavns Universitet.

Kvale, S., \& Brinkmann, S. (2009). InterView: Introduktion til et håndværk. Hans Reitzels Forlag.

Lahti, M., Hätönen, H., \& Välimäki, M. (2014). Impact of e-learning on nurses' and student nurses knowledge, skills, and satisfaction: A systematic review and meta-analysis. International Journal of Nursing Studies, 51(1), 136-149. https://doi.org/10.1016/j.ijnurstu.2012.12.017

Landri, P. (2013). Mobilising ethnographers investigating technologised learning. Ethnography and Education, 8(2), 239-254. https://doi.org/10.1080/17457823.2013.792512

Lave, J., \& Wenger, E. (1991). Situated learning: Legitimate peripheral participation (reprinted). Cambridge University Press.

Lave, J., \& Wenger, E. (2003). Situeret læring-Og andre tekster. Hans Reitzel.

Li, Z. ; T., Ming-Hsiu ;. Tao, Jinyuan ;. Lorentz, Chris. (2013). Switching to blended learning: The impact on students' academic performance. Journal of Nursing Education and Practice, 4(3).

Lindblad, S., \& Sahlström, F. (2003). Klasserumsforskning. En oversigt med fokus på interaktion og elever. I J. Bjerg (Red.), Pædagogik-En grundbog til et fag (3. udg., s. 243-276). Hans Reitzels Forlag.

Lyngsø, A. (2015). At Home with Students - Observing Online and Offline Contexts. Seminar.net. Media, Technology \& Lifelong Learning, 11(1). https://journals.hioa.no/index.php/seminar/article/view/2362

Lyngsø, A. (2019). Etnografisk forløbsstudie i netbaseret sygeplejerskeuddannelse: Mellem skolen, hjemmet og klinikken: Ph.D.-afhandling. Københavns Universitet, Det Humanistiske Fakultet, Institut for Medier, Erkendelser og Formidling.

Lyngsø, A., \& Kirketerp Nielsen, C. (2016). Alternative rum til læring? Tidsskrift for Professionsstudier, 12(23), 18. https://doi.org/10.7146/tfp.v12i23.96721

Mackay, H. (2005). New connections, familiar settings: Issues in the ethnographic study of new media use at home. I C. Hine (Red.), Virtual Methods: Issues in Social Research on the Internet (s. 129-140). Berg.

Mathiasen, H., Rootzén, H., \& Thyregod, C. (2019). Gymnasieelevers dømmekraft-Et undervisningskontekstuelt it-anvendelsesperspektiv. Tidsskriftet Læring \& Medier, 12(21). 
McCutcheon, K., Lohan, M., Traynor, M., \& Martin, D. (2015). A systematic review evaluating the impact of online or blended learning vs. Face-to-face learning of clinical skills in undergraduate nurse education. Journal of Advanced Nursing, 71(2), 255-270. https://doi.org/10.1111/jan.12509

McIntyre, M., McDonald, C., \& Racine, L. (2013). A critical analysis of online nursing education: Balancing optimistic and cautionary perspectives. The Canadian Journal of Nursing Research = Revue Canadienne De Recherche En Sciences Infirmieres, 45(1), 36-53.

Olesen, M. I. K. (2020). Jeg vil have rigtig undervisning! Profiler af blendede learnere i efter- og videreuddannelsen. Tidsskriftet Læring \& Medier, 12(22).

Parker Webster, J., \& Marques da Silva, S. (2013). Doing educational ethnography in an online world: Methodological challenges, choices and innovations. Ethnography and Education, 8(2), 123-130. https://doi.org/10.1080/17457823.2013.792508

Parlakkilic, A. (2015). Modular Rapid E-Learning Framework (MORELF) in Desktop Virtualization Environment: An Effective Hybrid Implementation in Nurse Education. Turkish Online Journal of Distance Education, 16(1), 3-18.

Patterson, B. J., Krouse, A. M., \& Roy, L. (2012). Student outcomes of distance learning in nursing education: An integrative review. Computers, Informatics, Nursing: CIN, 3O(9), 475-488. https://doi.org/10.1097/NXN.obo13e3182573ad4

Pols, J., \& Moser, I. (2009). Cold technologies versus warm care? On affective and social relations with and through care technologies. ALTER - European Journal of Disability Research / Revue Européenne de Recherche Sur Le Handicap, 3(2), 159-178. https://doi.org/10.1016/j.alter.2009.01.003

Posey, L., \& Pintz, C. (2017). Transitioning a bachelor of science in nursing program to blended learning: Successes, challenges \& outcomes. Nurse Education in Practice, 26, 126-133.

Rambøll. (2016). Kortlægning. E-læring på videregående uddannelser.

Røn Noer, V. (2016). "Rigtige sygeplejersker”. Uddannelsesetnografiske studier af sygeplejestuderendes studieliv og dannelsesprocesser. Ph.d. Afhandling. Det Humanistiske Fakultet. Københavns Universitet.

Salmon, G. (2002). E-tivities: The key to active online learning. Kogan Page ; Stylus Pub.

Salmon, G. (2011). E-moderating: The key to online teaching and learning (3rd ed). Routledge.

Sword, T. S. (2012). The transition to online teaching as experienced by nurse educators. Nursing Education Perspectives, 33(4), 269-271.

Uddannelses- og Forskningsministeriet. (2008). Bekendtgørelse om uddannelsen til professionsbachelor $i$ sygepleje. https://www.retsinformation.dk/pdfPrint.aspx?id=114493

Uddannelses- og Forskningsministeriet. (2016). Bekendtgørelse om uddannelsen til professionsbachelor $i$ sygepleje. https://www.retsinformation.dk/forms/ro710.aspx?id=181963

Voutilainen, A. ; S., Terhi ;. Sormunen, Marjorita. (2017). Conventional vs. E-learning in nursing education: A systematic review and meta-analysis. Nurse Education Today, 50, 97-103.

Walford, G. (2008). The nature of educational ethnography. I G. Walford (Red.), How to do educational ethnography (s. 1-15). Tufnell Press.

Webb, L., Clough, J., O'Reilly, D., Wilmott, D., \& Witham, G. (2017). The utility and impact of information communication technology (ICT) for pre-registration nurse education: A narrative synthesis systematic review. Nurse Education Today, 48, 160-171.

Wulf, C. (2012). Towards a Historical Cultural Anthropology of Education: The Berlin Ritual Study. I K. M. Anderson-Levitt (Red.), Anthropologies of Education. A global guide to ethnographic studies of Learning and Schooling (s. 21). Berghahn Books. 


\section{Forfattere}

\section{Anita Lyngsø}

Lektor, ph.d.

VIA University College, Sygeplejerskeuddannelsen \&

Program for Læring og IT, Forskningcenter for Pædagogik og dannelse

\section{Karen Borgnakke}

Professor, dr.pæd.

Københavns Universitet, Sektion for Pædagogik
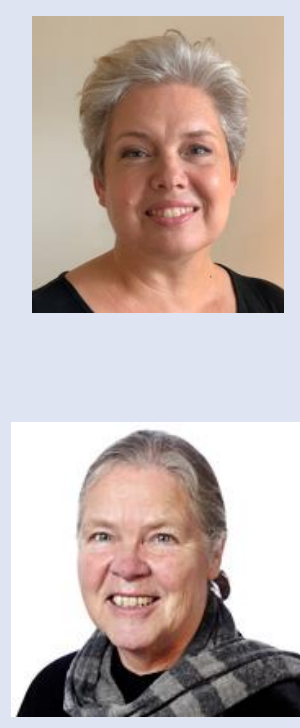

' Den samlede fremstilling af forløbsstudierne gives i ph.d.-afhandlingen "Etnografisk forløbsstudie i netbaseret sygeplejerskeuddannelsen - mellem skolen, klinikken og hjemmet" (Lyngs $\varnothing 2019)$. Det etnografiske feltarbejde blev gennemført af Anita Lyngs $\varnothing$ som ph.d.-projekt i et samarbejde mellem VIA University College, Sundhed, Viborg og Department of Communication, University of Copenhagen. Karen Borgnakke har fulgt Projekt Netuddannelsen som forskningskonsulent. 